\title{
PENGESAHAN PERKAWINAN BEDA AGAMA DALAM PERSFEKTIF HUKUM HINDU
}

\author{
NI NYOMAN RAHMAWATI \\ IAHN Tampung Penyang Palangka Raya \\ ninyomanrahmawati0202@gmail.com
}

\begin{abstract}
ABSTRAK
Perkawinan beda agama dewasa ini marak terjadi di tengah-tengah masyarakat. Hal ini tidak terlepas dari adanya pengakuan pluralitas agama yang diakui secara resmi oleh pemerintah Indonesia. Ada enam agama resmi yang diakui di Indonesia yaitu, agama Islam, Kristen, Protestan, Hindu, Budha, dan Kong Hu Chu. Namun demikian Perkawinan beda agama di Indonesia belum diatur secara tegas dalam perundang-undangan yang ada. karenanya masih terjadi perbedaan artikulasi dalam melihat dan memahami perkawinan beda agama di tengah-tengah masyarakat. untuk itu dalam karya ilmiah ini penulis mengangkat tentang pengesahan perkawinan beda agama dalam persfektif hukum Hindu, Dengan rumusan masalah (1) Bagaimanakah bentuk Perkawinan secara umum yang diatur dalam UU No 1 Tahun 1974?; (2) Bagaimanakah Pandangan Hindu terhadap sahnya perkawinan beda agama di tengah-tengah masyarakat?; (3) Bagaimanakah Bentuk penyelesaian perkawinan beda agama dalam persfektif hukum Hindu? Karya ilmiah ini menggunakan metode penulisan normative dengan mengacu kepada berbagai literature atau pustaka berupa bahan hukum primer seperti UU Perkawinan No 1 Tahun 1974, dan sekunder. Hasil yang diperoleh menunjukkan bahwa bentuk perkawinan dianggap sah sesuai UU RI No. 1 Tahun 1974 pasal 2 ayat 1 jika dilaksanakan sesuai dengan agama dan keyakiannya masing-masing. Ayat 2 perkawinan tersebut harus didaftarkan sesuai dengan peraturan perundangundangan yang berlaku. Pandangan Hindu terhadap sahnya perkawinan beda agama di tengah-tengah masyarakat dianggap sah apabila dilaksanakan sesuai dengan hukum agama Hindu, dilaksanakan dengan ritual Hindu (pabiokawonan) yang dipimpin oleh seorang pendeta atau pinandita. Penyelesaian perkawinan beda agama dalam hukum Hindu dilaksanakan dengan ritual sudhiwadani (ritual pengukuhan untuk masuk menjadi penganut agama Hindu) bagi pasangan pengantin yang belum menganut agama Hindu.
\end{abstract}

Kata Kunci: Pengesahan, Perkawianan Beda Agama, Persfektif Hukum Hindu 


\section{Pendahuluan}

Perkawinan merupakan jenjang kehidupan yang sangat penting dalam fase kehidupan manusia. Dalam ajaran Hindu disebutkan ada lima jenjang kehidupan yang diharus dilalui sebagai manusia yang disebut sebagai Catur Asrama di antaranya yaitu (1) Brahmacari, masa di mana seseorang berada dalam fase kehidupan menuntut ilmu sebagai bekal dalam menjalani fase-fase kehidupan berikutnya; (2) Grehasta, masa di mana seseorang berada dalam jenjang kehidupan berumah tangga; (3) Wana Prastha masa seseorang mulai melepaskan diri dari berbagai ikatan keduniawian dengan lebih fokus kepada tujuan kehidupan spiritual; dan (4) Bhiksuka masa di mana seseorang hidup hanya dari pemberian.

Grehasta sebagai fase kehidupan berumah tangga merupakan jenjang terpenting dalam kehidupan seseorang. Hal ini dikarenakan dalam jenjang kehidupan ini seseorang mengalami perubahan status dari konsumtif menjadi produktif, di samping juga dalam jenjang kehidupan grehasta seseorang mulai memikul tanggung jawab tidak hanya dalam lingkup rumah tangga tetapi juga dalam kehidupan bermasyarakat. Tanggung jawab tersebut baik dalam bentuk dharma agama maupun dharma negara. Khusus untuk menjalankan kewajiban dharma agama dalam ajaran Hindu disebutkan seseorang yang sudah menikah 
mulai dituntut untuk melaksanakan Panca Yadnya di antaranya yaitu Dewa Yadnya, , Rsi Yadnya, Manusia Yadnya, Fitra Yadnya, dan Bhuta Yadnya,.

Terkait dengan tanggung jawab dharma agama yang harus di tanggung oleh seorang grehastin sebagimana terdapat dalam Manawadharma Sastra (IX,96) disebutkan

"Prnja nartha striyah srstah

Samtanartham ca manawah

Tasmat sadharano dharmah

Srutau patnya sahaditah"

Artinya:

Untuk menjadi ibu, wanita itu diciptakan dan untuk menjadi ayah, lakilaki itu diciptakan. Upacara keagamaan di dalam Weda untuk dilakukan oleh suami bersama dengan istrinya.

Dari sloka tersebut di atas sangat jelas bahwa dalam menjalankan Dharma Agama suami istri dituntut untuk melakukan kerjasama, karenanya sangat di perlukan kesamaan pemahaman, pemikiran, dan tindakan antara suami istri sehingga mampu saling membantu satu sama lainnya. Karena itu dalam kehidupan berumah tangga akan menjadi baik apabila suami istri tersebut ada dalam satu keyakinan yang sama sehinga dapat saling melengkapi dalam melaksanakan kewajiban sebagai grehastin.

Namun demikian, fenomena pluralitas agama yang ada di Indonesia menjadikan perkawinan antara dua individu yang memiliki keyakinan berbeda secara realita sering terjadi. Hal ini tentunya memicu terjadinya berbagai 
permasalahan baik antara individu itu sendiri maupun antara kedua keluarga mempelai dalam menentukan agama mana yang akan di pilih sebagai salah satu agama yang akan mereka yakini. Hal ini mengingat UU Perkawinan Pasal 1 Tahun 1974 walaupun secara tegas mengatakan bahwa sebuah perkawinan dianggap sah apabila dilaksanakan sesuai dengan keyakinan yang di miliki namun, belum ada penjelasan lebih lanjut yang bisa diacu oleh masyarakat Hindu yang menikah beda agama. Namun demikian pasal ini dapat diinterpretasikan bahwa sebelum seseorang melaksanakan sebuah perkawinan, mereka harus menyamakan dulu agama mereka barulah kemudian dapat dilaksanakan perkawinan. Terkait dengan hal ini maka penulis ingin mengangkat tentang Pengesahan Perkawinan Beda Agama Dalam Persfektif Hukum Hindu.

Karya ilmiah ini menggunakan metode penulisan normative dengan mengacu kepada berbagai literature atau pustaka. Di samping itu penulisan karya ilmiah ini juga menggunakan bahan hukum primer seperti UU Perkawinan No 1 Tahun 1974, dan sekunder tertier. Dengan tiga rumusan masalah yaitu: (1) Bagaimanakah bentuk Perkawinan secara umum yang diatur dalam UU No 1 Tahun 1974?; (2) Bagaimanakah Pandangan Hindu terhadap sahnya perkawinan beda agama di tengah-tengah masyarakat?;

Bagaimanakah Bentuk penyelesaian Perkawinan Beda Agama dalam persfektif hukum hindu? 



\section{Pembahasan}

\section{Perkawinan secara umum yang diatur dalam UU No 1 Tahun 1974}

Perkawinan merupakan ikatan lahir batin antara seorang pria dengan seorang wanita sebagai suami istri untuk membentuk kehidupan rumah tangga yang berbahagia.. Dalam Peraturan perundang-undangan RI No.1 Tahun 1974 pasal 1 ayat 1 disebutkan bahwa perkawinan adalah ikatan lahir batin antara seorang pria dan seorang wanita sebagai suami istri dengan tujuan membentuk keluarga atau rumah tangga yang bahagia dan kekal berdasarkan Ketuhanan Yang Maha Esa.

Sahnya sebuah perkawinan menurut UU RI NO. 1 Tahun 1974 pasal 2 Ayat 1 adalah apabila dilakukan menurut hukum masing-masing agama dan kepercayaannya itu. Dan Ayat 2 menyatakan bahwa sebuah perkawinan dianggap sah apabila sudah dicatat menurut perundang-undangan yang berlaku. Dari pasal 2 ayat 1 di atas, masyarakat memahami bahwa sebuah perkawinan di anggap sah apabila kedua mempelai telah menganut agama yang sama. Misalnya jika terjadi perkawinan antara seorang pria beragama Islam dengan perempuan yang beragama Hindu maka salah satu dari mereka harus pindah keyakinan sesuai dengan kesepakatan setelah itu barulah perkawinan bisa dilaksanakan, dan setelahnya perkawinan tersebut harus sudah dicatat menurut perundang-undangan yang berlaku. Di mana bagi perkawinan yang dilakukan oleh umat Islam baru dianggap sah apabila sudah 
dicatat di KUH. Sementara itu bagi perkawinan yang dilaksanakan dalam keyakinan selain Islam harus dicatat di catatan sipil.

Selain itu sebuah perkawinan bisa dilaksanakan jika sudah memenuhi beberapa persyaratan menurut UU Nomor 1 tahun 1974 tentang perkawinan, di antaranya yaitu:

1. Adanya persetujuan kedua mempelai

2. Adanya ijin kedua orang tua atau wali bagi mempelai yang belum berusia 21 tahun

3. Usia calon mempelai pria sudah mencapai 19 tahun dan usia calon mempelai wanita sudah mencapai 16 tahun

4. Antara calon mempelai pria dan calon mempelai wanita tidak dalam hubungan darah atau keluarga yang tidak boleh kawin

5. Tidak berada dalam ikatan perkawinan dengan pihak lain

6. Bagi suami istri yang telah bercerai, lalu kawin lagi satu sama lain dan bercerai untuk kedua kalinya, agama dan kepercayaan mereka tidak melarang mereka kawin untuk ketiga kalinya

7. Tidak berada dalam waktu tunggu bagi calon mempelai wanita yang janda Terlepas dari semua persyaratan sahnya sebuah perkawinan menurut UU perkawinan di atas, perkawinan beda agama di Indonesia masih diwarnai oleh berbagai polemik. Hal ini dikarenakan masih belum adanya aturan jelas dan tegas yang mengatur tentang perkawinan beda agama. Padahal dalam 
realitasnya perkawinan beda agama di tengah-tengah masyarakat sangat marak terjadi. Hal ini tidak terlepas dari pluralitas agama yang ada di Indonesia. Indonesia sebagai negara yang memiliki tingkat pluralitas agama yang sangat tinggi mengakui adanya enam agama resmi di antaranya, yaitu agama Islam, Kristen, Protestan, Hindu, Budha, dan Kong Hucu. Hal ini sangat memungkinkan terjadinya perkawinan beda agama di tengah-tengah masyarakat.

\section{Perkawinan Beda Agama dalam Pandangan Hindu}

Setiap agama memiliki pandangan dan makna tersendiri terhadap perkawinan yang laksanakan. Demikian juga agama Hindu sebagai salah satu agama resmi yang diakui keberadaanya oleh negara Indonesia juga memiliki aturan tersendiri tentang perkawinan yang dilaksanakan oleh umatnya. Perkawinan dalam konsep agama Hindu disebut sebagai masa Grhastha yang berasal dari kata "grh" yang artinya rumah. Jadi grhastha adalah masa di mana seseorang hidup berumah tangga. Untuk menciptakan kehidupan berumah tangga didahului dengan sebuah perkawinan (wiwaha samkara). Secara etimologi pawiwahan berasal dari kata "wiwaha"yaitu dalam bahasa Sansekerta dalam Kamus Bahasa Indonesia di artikan sebagai pesta pernikahan; perkawinan (Departemen Pendidikan dan Kebudayaan, 1997:1130) 
Menurut hukum Hindu perkawinan (wiwaha) tidak hanya sekedar penyatuan antara seorang pria dan wanita dengan tujuan hidup sebagai suami istri guna mendapatkan keturunan dan membina sebuah keluarga (Prem P Bhalla, 2010: 128). Namun lebih jauh perkawinan (wiwaha) dalam ajaran Hindu merupakan jembatan menuju kehidupan berumah tangga untuk membentuk keluarga yang berbahagia lahir dan bhatin. Keluarga yang dibentuk dalam perkawinan oleh umat Hindu merupakan suatu ikatan kasih dalam pengabdian antara suami, istri, dan anak . Bahkan menurut Jaman (2008:10) mengartikan keluarga sebagai persatuan yang terjalin di antara seluruh anggota keluarga adalah dalam rangkaian pengabdian yang mesti diemban oleh anggota keluarga yang bersangkutan.

Perkawinan dalam ajaran Hindu merupakan sebuah yadnya sehingga dipandang sangat sakral. Hal ini dikarenakan perkawinan dalam Hindu adalah bertujuan untuk mendapatkan keturunan dan memberikan peluang bagi para leluhur untuk menjelma kembali ke dunia ini (Natih,1995 : 18). Bahkan Titib (2003:394) mengatakan bahwa tujuan perkawinan dalam ajaran Hindu itu ada tiga yaitu Dharmasampatti (bersama-sama suami dan istri mewujudkan pelaksanaan Dharma); praja (melahirkan keturunan); dan rati (menikmati kehidupan seksual dan kepuasan indria lainnya).

Perkawinan (wiwaha) sebagaimana terdapat dalam kitab Manawa Dharmasasra Pasal III Ayat 21 disebutkan bahwa ada delapan cara perkawinan 
(wiwaha) yang dilakukan oleh umat Hindu, diantaranya : (1) Brahmana Daiwa, (2) Rsil Arsa, (3) Prajapati, (4) Asura, (Gandharwa), (5) Raksasa, dan (6) Paisaca/Pisaca. Adapun bunyi dari sloka tersebut di atas adalah:

"Brahmo daiwastathaiwarsah

Prajapatyastathasurah

Gandharwo raksasaccaiwa

Paicacacca astamo dharmah"

$\underline{\text { Namun demikian tidak semua cara perkawinan di atas dipandang baik }}$ oleh para rsi dan dapat disahkan dalam hukum perkawinan Hindu. Sebagaimana bunyi ayat 25 sebagai berikut:

"Pancanam tu trayo dharmya

Dwawadharmyau smrtawiha

Paicacaccasuraccaiwa

Na kartawyau kadacana"

Artinya:

“ Tetapi menurut peraturan undang-undang ini tiga dari lima bagian akhir dinyatakan sah Sedangkan dua (lainnya) tidak sah, picaca dan Asurawiwaha tidak boleh dilakukan sama sekali".

Pawiwahan dalam ajaran Hindu sebagaimana bunyi sloka di atas, memandang bahwa perkawinan yang dilakukan dengan cara kekerasan (pemaksaan) sama sekali tidak dianjurkan karena bisa berdampak tidak baik terhadap kelangsungan perkawinan kedepannya. sebagaimana dilaksanakan sesuai dengan petujuk dalam kitab suci Veda. Perkawinan (wiwaha) dalam ajaran Hindu juga merupakan penyucian diri melalui Grhastha Asrama (sarira samkara). Bahkan menurut Arthayasa, (1998:18-19) perkawinan merupakan sebuah ritual yang memberikan kedudukan sah dan tidaknya seorang dalam 
menjalani hidup bersama.seorang pria dan wanita. Jadi perkawinan juga merupakan sebuah yadnya.

Menurut Arthayasa, (1998:11) secara umum syarat perkawinan dalam ajaran agama Hindu ada dua yaitu, (1) syarat yang bersifat lahiriah meliputi faktor usia, hal ini sangat penting diperhatikan dalam sebuah perkawinan karena perbedaan umur antara pria dan wanita secara psikologis membawa dampak dalam kehidupan berumah tangga. dan status (tidak terikat perkawinan dengan orang lain), dan berbadan sehat. (2) yang bersifat batinia meliputi mempunyai keimanan yang sama (satu agama), dan saling mencintai.

Dalam hukum Hindu persyaratan untuk sahnya sebuah perkawinan adalah : (1) suatu perkawinan menurut hukum Hindu sah jika dilakukan menurut ketentuan hukum Hindu, (2) untuk mengesahkan perkawinan menurut Hukum Hindu harus dilkukan oleh Pendeta/ Pinandita, (3) Suatu perkawinan hanya dapat disahkan menurut Hukum Hindu jika kedua mempelai telah menganut agama Hindu. Dari persyaratan di atas dapat dipahami bahwa perkawinan yang salah satu diantaranya belum menganut Hindu atau kedua-duanya bukan penganut agama Hindu maka perkawinan itu tidak dapat di sahkan menurut Hukum Hindu 


\section{Penyelesaian Perkawianan Beda Agama Dalam Pesfektif Hukum Hindu}

Sebagaimana uraian di atas, dalam Hukum Hindu juga tidak mengesahkan perkawinan yang dilakukan oleh orang yang bukan beragama Hindu atau salah satu mempelai tidak beragama Hindu (berbeda agama). Karena itu jika ingin menikah dan dianggap sah secara hukum Hindu maka pasangan yang belum beragama Hindu harus pindah menjadi penganut agama Hindu melalui ritual Sudhiwadani. Ritual Sudhiwadani diilakukan sebelum ritual pernikahan dilaksanakan. Ritual Sudhiwadani dipimpin oleh seorang Pinandita/ Pandita dengan di saksikan oleh trisaksi yaitu: Dewa Saksi, Manusia Saksi dan Bhuta Saksi.

Ritual Sudhiwana merupakan ritual pengukuhan bagi umat non Hindu yang ingin konversi ke agama Hindu. Dalam pelaksanaanya ada beberapa persyaratan yang harus dipenuhi, yaitu (2) Membuat surat pernyataan dengan tulus iklas untuk menganut agama Hindu, tanpa ada tekanan atau paksaan dari pihak lain; (2) Membuat surat permohonan kepada Parisada Hindu Dharma Indonesia setempat; (3) Melengkapi administrasi berupa surat permohonan untuk sudhiwadani, Pas photo, dan foto copy KTP.

Selain persyaratan administrasi di atas, dalam pelaksanaan ritual sudhiwadani juga harus dilengkapi beberapa sarana berupa sesajen, di antaranya yaitu (1) Sesajen Byakala; (2) Prayascita; (3) Pejati; dan sesajen pelengkap 
lainnya; (4) air suci; serta (5) api/ dupa. Dalam pelaksanaanya ritual Sudhiwadani melalui beberapa tahapan diantaranya, yaitu:

1. Mengajukan surat permohonan kepada Parisada (PHDI) setempat dengan melampirkan surat peryataan masuk agama Hindu, foto, dan foto copy KTP

2. Parisada (PHDI) berdasarkan surat permohonan tadi kemudian menugaskan salah satu Rohaniawan untuk memimpin ritual tersebuat

3. Ritual dilaksanakan sesuai dengan tanggal yang telah ditentukan, untuk pasangan yang akan menikah biasanya dilaksanakan di rumah pihak pasangan yang sudah terlebih dahulu menganut agama Hindu

4. Pada saat pelaksanaan juga dihadirkan saksi-saksi dari masyarakat sekitar

5. Diakhir pelaksanaan ritual, PHDI juga menunjuk salah satu jajarannya untuk memberikan wejangan dasar sebagai penganut Hindu

6. Setelah prosesi Sudhiwadani selesai dilaksanakan kemudian dilakukan penanda tanganan 


\section{Kesimpulan}

1. Perkawinan beda agama di Indonesia masih belum diatur secara tegas dalam UU Perkawinan. Namun demikian perkawinan dianggap sah sesuai UU Perkawinan No 1 Tahun 1974 jika perkawinan itu dilaksanakan sesuai dengan keyakinan dan kepercayaanya masing-masing: perkawinan itu juga harus didaftarkan sesuai dengan perundang-undangan yang ada.

2. Hukum Hindu menganggap sah sebuah perkawinan beda agama jika perkawinan tersebut dilaksanakan sesuai dengan Hukum Hindu dan dipimpin oleh seorang pendeta /pinandita Hindu

3. Penyelesaian perkawinan beda agama dalam Hukum Hindu dilaksanakan dengan ritual sudhiwadani (ritual pengukuhan bagi mempelai yang belum menganut agama Hindu). 


\section{Daftar Pustaka}

Bhalla. Prem.P. 2010. Tatacara Ritual dan Tradisi Hindu. Paramita: Surabaya

Jaman. I Gede. 2008. Membina Keluarga Sejahtera.Paramita: Surabaya

Pudja. G. 2002. Manawa Dharmasastra. Pelita Nusantara Lestari: Jakarta

Suastika Eakasana. I Made. 2012. Dharma Bandhu: Hukum Kekeluargaan Hindu. Paramita: Surabaya

Arthayasa. I Nyoman. 1998. Petunjuk Teknis Perkawinan Hindu. Paramita:

Surabaya

Tim Penyusun. 1998.Tuntunan Pelaksanaan Sudhi Wadani. Departemen Agama

RI Jakarta

Tatacara Sudhi Wadani (https//pandejuliana. Wordpress.com. diakses tanggal

12 Juni 2019)

Rahmawati. Ni Nyoman. Upacara Sudhi Wadani dalam Persfektif Hukum Hindu. Jurnal Belom Bahadat Vol III 1 April 2013

Karmini. Ida Ayu Putu. 2013. Eksistensi Upacara Sudhi Wadani di Desa Basarang Jaya Kec. Basarang Kabupaten Kapuas Persfektif Hukum Hindu. Skripsi STAHN-TP Palangka Raya

UU Perkawinan No. 1 Tahun 1974

Natih, Ni Ketut, dkk. 1980. Pembinaan Perkawinan Agama Hindu. Yayasan Dharma Kerti: Jakarta

Titib. I Made. 2003. Veda Sabda Suci: Pedoman Praktis Kehidupan. Paramita:

Surabaya. 